London, where so many alternative streets are available for an intelligent driver. In addition, the science of mechanical engineering advances so rapidly that steep road gradients which render a road unpopular at present may in ten years time offer practically no hindrance to a motor-car. Any attempt to replan an ancient capital must be largely empirical ; opportunism must play a leading part. The inertia of habit is a powerful force. Theoretical considerations have to be tempered by common sense based on a general knowledge of London's development and of the improvements which have been carried out or rejected during past years. However carefully the flow of traffic be recorded, we are still at a loss to account for the underlying causes of the waywardness. The mysterious flittings of trade and industry influence the distribution of the nation's population. The advantages of undeviating directness over great distances, unhesitatingly accepted by the Roman road engineers, who were untrammelled by county boundaries and ring fences around estates, would not be accepted implicitly to-day.

\section{Archæological Discoveries on Monte Alban, Mexico}

Excavatron of the Mixteco-Zapotecan necropolis on Monte Alban, near Oaxaca, Mexico, which has been in progress under the direction of Dr. Alfonso Caso without interruption since 1932, has produced a remarkable assemblage of objects, ornamental and ceremonial, in gold, semi-precious stone, or other material, illustrating the religion, life and customs of these peoples. In large measure the remarkable character of the finds justifies the dictum of the excavator that in the archæological sense this is the most important region in the whole of the Americas, not even excepting the Peruvian site of Cuzco. When one hundred and two tombs had been explored, the site was visited in the course of the past year by General L. Cardenas, President of the Republic. The occasion was marked by the opening of three further tombs, which the President, accompanied by Señor Caso, was the first to enter. The first tomb offered little calling for comment, but the second and third afforded the unexpectedly important and spectacular discovery of series of vivid polychrome frescoes adorning the walls. These depict gods and their symbols, as well as priests in ceremonial garb, sacred and mythological motives, and ritualistic symbols of life and death. In the third tomb, painted figurines were standing in ritual niches, and on the floor was a skeleton, obviously of a great chief, surrounded by a number of funerary objects, axes and knives in obsidian and flint, a green jade statuette of Quetzalcoatl, the Plumed Serpent of the Zapotecs, and a number of domestic and liturgical vessels. The mural decoration is considered to be the most important discovery yet made on Monte Alban. The President was so strongly impressed by the importance of the excavation that not only did he promise a Government subvention in order that the work might be continued, but also ordered an immediate grant of 10,000 piastres (approximately 60,000 francs). A brief account of the discovery and of the frescoes and contents of the tombs by Dr. Nuñez y Dominguez, secretary of the National Museum of Mexico, has recently appeared ( $J$. Soc. des Americanistes, N.S., $29,2)$.

\section{Insects of Cambridgeshire}

A LIMITED number of copies of the "Zoology of Cambridgeshire", the major part of which is occupied by the account of the Insecta, are now available. They are reprinted from the "Victoria County History of Cambridgeshire and the Isle of Ely", vol. 1, pp. 77-245 (1938), reviewed elsewhere in this issue (p. 46). Applications for these reprints, accompanied by a remittance of $£ 11 s$, which covers postage, should be made to the editor, Dr. A. D. Imms, Zoological Laboratory, Cambridge.

\section{Announcements}

DR. R. L. SмiтH-Rose has been appointed, as from January 1, superintendent of the Radio Department of the National Physical Laboratory, which includes the Radio Research Station at Slough in addition to the section of the Department at Teddington. Dr. Smith-Rose has been principal scientific officer-in-charge of the Departments ince Mr. Watson Watt left the Laboratory in 1936 to take up a position in the Air Ministry.

A BIBLIOGRAPHY on the housing and equipment of school libraries, compiled by Ellen L. Anderson, has been issued by the Office of Education, United States Department of the Interior. The bibliography consists of an annotated and selected list of references intended to show what schools have done for their libraries and to give concrete suggestions to those interested in starting a school library or in improving an old one. The list is limited to the physical aspects of the library and administration.

IN NATURE of December 24, p. 1130, in an article on "Future Developments in Coal Treatment and Utilization", reference was made to a paper by Prof. A. C. G. Egerton and to experimental work described by Mr. Armstrong. Mr. Armstrong was said to be a research student from South Africa. We are informed that this is incorrect; Mr. Armstrong is from New Zealand.

THE National Research Council of Canada, Ottawa, announces the forthcoming publication in book form of a scientific account of a comprehensive study on the effect of sulphur dioxide on vegetation. The book covers an investigation carried out under the auspices of the National Research Council during the period 1929-38 on the effect on vegetation in Northern Stevens County, Washington, of sulphur dioxide from the large metallurgical plant at Trail, B.C., and also elaborate experiments planned to elucidate the many questions which arose in connexion with the investigation.

Erratum.-NAture, January 7, p. 34, article entitled "Structure of Proteins", col. 2, paragraph 2, last line, for "marked" read "masked". 